\title{
Current Approach to Primary Immunodeficiency Diseases
}

\author{
— Öner Özdemir
}

\section{Department of Pediatrics, Division of Allergy and Immunology, Sakarya University Faculty of Medicine, Adapazarı, Turkey}

Submitted: 18.07.2018 Accepted: 02.01.2019

Correspondence: Öner Özdemir Sakarya Üniversitesi Tıp Fakültesi, Çocuk Allerji-İmmünoloji Bilim Dalı, Adapazarı, Turkey

E-mail: oner.ozdemir.md@gmail.com

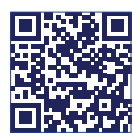

Keywords: Combined immunodeficiency; diagnosis; primary immunodeficiency disease; severe combined immunodeficiency.

\begin{abstract}
Primary immunodeficiency diseases (PIDD) are inherited disorders resulting from defects in diverse elements of the human immune system. Currently, more than 330 PIDDs have been described, and the molecular (genetic) bases for more than 320 of them are known. PIDD can be divided into nine different groups, including antibody (humoral) deficiencies, innate/intrinsic deficiencies, phagocytic system deficiencies, complement component deficiencies, combined ( $T$ and $B$ cells) immunodeficiencies, syndromic combined immunodeficiencies, immune dysregulation disorders, autoinflammatory diseases and phenocopies of PIDD. In the PIDD group, primary antibody deficiencies are the most common group, and approximately $50 \%$ of patients with PIDD fall into this group of deficiencies. Congenital primary immunodeficiencies typically appear early in life, although late onset is gradually more identified. Affected patients usually present clinically with recurrent/ severe infections, or clinical pictures resembling various autoimmune or other diseases. An early diagnosis of congenital immunodeficiencies is necessary for transfer to specialized medical centers, and prompt commencement of the optimal treatment, including transplantation and enhanced outcomes. In this review, a general approach is described for the investigation of the most common groups of PIDD, outlining the most appropriate laboratory investigations when the clinician comes across typical clinical pictures and/or infections suggesting immunodeficiency.
\end{abstract}

\section{INTRODUCTION}

In this review, an anamnesis (history of infection and disease) and laboratory findings will be evaluated together with laboratory tests relevant to the primary immunodeficiency disease (PID) group.

In most cases, the investigations focus on a certain PID group according to the type of infection or disease encountered in the clinic. For example, in cases of viral and fungal infections, the efforts are directed to $T$ cells, and in infections caused by encapsulated bacteria, B cells are implicated. In infections with certain microorganisms such as Neisseria meningitis, complement system dysfunction is implicated, whereas in Serratia and organ abscesses, an involvement of phagocytic cells, and in Herpes encephalitis, Toll-like receptor disorders, are suspected. ${ }^{[1]}$ Systemic lupus erythematosus (SLE) and hemolytic uremic syndrome are frequently seen diseases that suggest a dysfunction of the complement system; gingivit-stomatitis and abscesses imply phagocytic system disorders, and the sinopulmonary system diseases are suggestive of the humoral immune system (antibody deficiency) disorders. ${ }^{[1-9]}$

Apart from the infections we have encountered in the clinic, different disease types, including autoimmune cytopenia, thrombocytopenia, hepatosplenomegaly, eczema, telangiectasia, partial albinism, inflammatory bowel syndrome, chronic diarrhea, chronic giardiasis, chronic mucocutaneous candidiasis, pulmonary abscesses, pneumatoceles, recurrent fever, and rheumatic complaints may lead to immune system disorders that can be categorized in seven important groups (combined [cellular+humoral and syndromic] and phenocopic immunodeficiencies, phagocytosis, complement system deficiencies, immune dysregulation and natural/structural immune system response disorders, and autoinflammatory syndromes). ${ }^{[10]}$ After some basic screening tests are explained, we will talk about the tests that may be requested in the advanced stage. In this review, starting from antibody deficiencies (humoral immune system disorders), an approach to the five most known PID groups will be described.

\section{1) Evaluation of antibody deficits}

In our country, as well as in the world, antibody deficiencies are the most common PIDs we encounter. Selective $\lg \mathrm{A}$ deficiency and transient hypogammaglobulinemia in infants are among the leading disorders in our country. [11-15] Initially, quantitative immunoglobulin isotype values for age, screening tests, specific antibody levels after natural immunity (spontaneous) and immunization (vaccination), and IgG subgroup (IgGI-G2-G3-G4) levels are 
examined. In vitro functional studies that can evaluate Bcell immunophenotyping and antibody production can be performed in advanced centers. Again, especially in the differential diagnosis, in order to rule out thymoma in patients $>50$ years of age with low B-cell counts, thorax CT, sweat test for cystic fibrosis, fecal $\alpha$ l-antitrypsin, the urine protein/serum albumin level, absolute lymphocyte count, as well as tests to exclude loses with feces and urine or through the lymphatic system may be required (Table I).

Table I. Evaluation of suspected antibody deficiency syndromes

Tests of primary priority

Serum levels of immunoglobulin isotypes (IgG, $\lg A$, $\lg M$, and $\lg \mathrm{E})$

Serum specific antibody levels

Titers of antibodies against specific antigens of natural blood groups (isohemaglutinins)

Titers of specific antibodies against protein and carbohydrate antigens before and after vaccination Serum IgG subgroups

Tests of secondary priority

B-cell immune phenotyping (naive or class-switched memory cell, etc.)

In vitro functional tests (measurement of in vitro immunoglobulin production evoked by mitogen or other stimulus)

Tests used to exclude rarely seen etiologies

Thoracic computed tomography to exclude thymoma in hypogammaglobulinemic adults

Evaluation of complement deficiency ( $\mathrm{CH} 50$, AP50)

Genetic evaluation for BTK or SAP/XIAP proteins or

intracellular flow cytometry tests

Karyotype analysis for ICF syndrome characterized by

immune insufficiency, centromere instability, and

facial anomaly, monosomy 7 , trisomy 8 , and trisomy 21

(Down syndrome)

Genetic evaluation of NEMO to exclude anhidrotic ectodermal dysplasia progressing with ımmune deficiency Advanced genetic examination methods: microarray methods for variations in the number of gene copies; target gene panel sequencing; all exon/genome sequences

Tests used to exclude all other secondary etiologies

Sweat test or mutation analyses for cystic fibrosis

Determination of fecal alpha-I-antitripsin, urinary protein, serum albumin levels, and absolute lymphocyte counts for the assessment of protein loss through gastrointestinal, urinary, or lymphatic routes, respectively HIV test (anti-HIV test, and measurement of viral HIV load using PCR)

Ig: Immunoglobulin; BTK: Bruton thyrosine kinase; XLA: X-chromosome linked agammaglobulinemia; SAP: SLAM-associated protein; XIAP: X-chromosome linked inhibitor of apoptosis; $\mathrm{CH} 50$ : Total hemolytic complement activity; AP50: Alternative pathway hemolytic activity.
Immunoglobulin isotype values and their interpretation

There are no strict standards in the diagnosis of immunoglobulin (antibody) deficiency. According to the common assumption, the immunoglobulin value under two standard deviations for age is considered as deficiency, that is, hypogammaglobulinemia. Some experts say that age-appropriate reference (confidence) intervals $(95 \% \mathrm{Cl})$ should be evaluated. ${ }^{[3-9]}$ Levels below the normal values for that particular age require examination. The normal values for age were determined in studies conducted in our country. $\left[{ }^{[6,17]}\right.$ Regardless of the age-appropriate values in adolescents and adults, an $\mathrm{IgG}$ value $<300-400 \mathrm{mg} / \mathrm{dL}(3-4 \mathrm{~g} / \mathrm{L})$ and in infants $<100 \mathrm{mg} / \mathrm{dL}$ is evaluated as hypogammaglobulinemia without doubt. ${ }^{[3,6]}$ However, agammaglobulinemia is defined as an lgG value $<100 \mathrm{mg} / \mathrm{dL}$. Again, in this case $\operatorname{lgM}<20 \mathrm{mg} /$ $\mathrm{dL}, \operatorname{lgA}<10 \mathrm{mg} / \mathrm{dL}$, and peripheral blood CDI9 + - B-cell $<2 \%$ signify agammaglobulinemia. ${ }^{[8,18,19]}$

\section{Values of IgG subgroups and their interpretations}

The value of the immunoglobulin subgroup below two standard deviations with regard to age is considered to be deficiency. Some experts say that evaluations should be made according to an age-appropriate reference (confidence) intervals $(95 \% \mathrm{Cl}) .{ }^{6]}$ In particular, the evaluation of IgG subgroups in selective IgA deficiency patients with recurrent bacterial infections is particularly useful. If treatment of $\lg G$ subgroup deficiencies is expected to be initiated, it is necessary to show a specific antibody deficiency first.

Spontaneous/natural (specific) antibody (isohemaglutinin) titers

Spontaneous specific antibody titer is the anti-lgG (isohemaglutinin) titer, which is formed against the blood group natural polysaccharide antigens. It also occurs partially in response to polysaccharides in the intestinal flora. Antibodies against blood groups A and B may not develop in the first I-2 years of life, especially within the first 6 months. Isohemagglutin is not found in patients with the blood group AB. Again, under the age of $\mathrm{I}-2$, the response of isohemagglutinin cannot be trusted. ${ }^{[2]}$ In general, $\geq 1: 4$ titer is adequate in small children, while in adolescents and adults, $\geq 1: 10$ is considered adequate. ${ }^{[20]}$ These tests are more useful in differentiating transient hypogammaglobulinemia from permanent Bruton or CVID (common variable immune deficiency) (Table 2a). ${ }^{[2-9]}$

Specific antibody responses to protein/ polysaccharide vaccines

First of all, patients should be examined for the presence of a protective titer. If there is no protective titer, one dose of vaccine is given, and 2-4 weeks later, a four-fold increase observed in protein vaccines and a two-fold increase in polysaccharide vaccines are considered to be an adequate response. Normally, these titers are expected to continue for more than 6 months. There is no response to more than $50 \%$ of the serotypes of the pneumococcal vac- 
cine in children with a specific antibody deficiency, above the protective titer of $1.3 \mathrm{ug} / \mathrm{ml}$ in children aged $<6$ years. In children $>6$ years of age, there is no response to more than $70 \%$ of serotypes of the vaccine. Some details on how to evaluate these vaccine responses are shown in Table $2 b$.

Titers of other routine/known vaccines (tetanus, diphtheria, Hib, meningococci, polio, MMR) can also be sought for. Since the patients receiving IVIG will have antibodies against other known antigens, Bacteriophage (Phi) $\phi \times 174$ called neoantigen developed against it will be investigated. Also known past diseases (EBV, CMV, Varicella-Zoster, etc.) are evaluated during the post-infectious period, and antibody titers against them are examined. Specific an-

Table 2a. Age-adjusted titers of isohemaglutinin and their evaluation (adopted from the $20^{\text {th }}$ reference)

\begin{tabular}{lcc}
\hline Age & Anti-A titer & Anti-B titer \\
\hline $0-6$ mos & Unknown (?) & Unknown (?) \\
6 mos-2 years & $>1 / 4$ & $>1 / 4$ \\
$2-10$ years & $>1 / 4$ & $>1 / 16$ \\
$>10$ years & $>1 / 4$ & $>1 / 4$ \\
Adolescent/Adult & $>1 / 10$ & $>1 / 10$ \\
\hline
\end{tabular}

tibody tests, such as isohemagglutinin, are also used to distinguish transient hypogammaglobulinemia from permanent hypogammaglobulinemias (Bruton or CVID [diffuse variable immunodeficiency, etc.]). ${ }^{[2-9]}$

As a result, antibody deficiency (humoral deficiency) and its type are tried to be diagnosed based on the presence of the immunoglobulin isotype (group), lgG subgroup, vaccine response, and B cells in the blood (Table 3).

\section{2) Assessment of cellular (and combined) immunodeficiency}

As a screening test, it is necessary to show whether lymphopenia is primarily related to an HIV infection (by measuring anti-HIV and HIV viral load). Lymphocyte immunophenotyping and skin tests for delayed-type hypersensitivity are included in these basic screening tests. Among advanced stage tests T-cell proliferation (mitogen, recall), T-cell cytokines, flow cytometric intracellular and cell surface detection (WASP, SAP intracellular molecules and CD40L: CDI54, IL-2R $\gamma$ (gamma) chain: CDI32, IL7R $\alpha$ : CDI27, MHC-I/II surface expressions, etc.), enzyme studies (ADA, PNP, etc.), FISH, T-cell receptor excision circles (TREC), T-cell receptor repertoire, and mutation analysis are available (Table 4 ).

Table 2b. Evaluation of the responses obtained with protein, conjugated, and polysaccharide vaccines

\begin{tabular}{lcccc}
\hline Types of Vaccines & $\begin{array}{c}\text { T-cell } \\
\text { dependency }\end{array}$ & $\begin{array}{c}\text { Antibody response } \\
\text { against }\end{array}$ & $\begin{array}{c}\text { Maximum } \\
\text { antibody titer }\end{array}$ & $\begin{array}{c}\text { Protective } \\
\text { titer }\end{array}$ \\
\hline Tetanus & Dependent & Protein & $2-3$ weeks after primary vaccination & $0.15 \mathrm{IU} / \mathrm{mL}$ \\
Diphtheria & Dependent & Protein & $2-3$ weeks after primary vaccination & $0.01 \mathrm{IU} / \mathrm{mL}$ \\
Hib:PRP+protein carrier & Dependent & Protein & 4 weeks, after the third dose of vaccine & $1.0 \mu \mathrm{g} / \mathrm{mL}$ \\
Meningococal (conjugated) & Dependent & Protein & $2-4$ weeks & $2.0 \mu \mathrm{g} / \mathrm{mL}$ \\
Pneumococcal (conjugated) & Dependent & Protein & $2-4$ weeks & $1.3 \mu \mathrm{g} / \mathrm{mL}$ \\
Pneumococcal (polysaccharide) & Independent & Polysaccharide & 4 weeks & $1.3 \mu \mathrm{g} / \mathrm{mL}$ \\
\hline
\end{tabular}

Table 3. Possible diagnostic types of hypogammaglobulinemias according to serum immune globulin, responses to vaccines, and presence of $\beta$ cells (adapted from the $8^{\text {th }}$ reference)

\begin{tabular}{|c|c|c|c|c|c|c|}
\hline IgG & IgA & $\lg M$ & IgGI-4 & Vaccine response & B-cell & Possible diagnoses \\
\hline $\mathrm{N}$ & $\mathrm{N}$ & $\mathrm{N}$ & $\mathrm{N}$ & $\mathrm{N}$ & $\mathrm{N}$ & Normal \\
\hline $\mathrm{N}$ & $\mathrm{N}$ & $\mathrm{N}$ & $\mathrm{N}$ & D (PS) & $\mathrm{N}$ & SAD \\
\hline $\mathrm{N}$ & $\mathrm{N}$ & $\mathrm{N}$ & $>I D$ & $\mathrm{D}(\mathrm{PS})$ & $\mathrm{N}$ & IGGSD \\
\hline $\mathrm{N}$ & None & $\mathrm{N}$ & $\mathrm{N}$ & N/D & $\mathrm{N}$ & SIGAD \\
\hline $\mathrm{N}$ & None & $\mathrm{N}$ & $>I D$ & D (PS) & $\mathrm{N}$ & $\operatorname{IgA+IGGSD}$ \\
\hline$D$ & $\mathrm{~N}$ & $N$ & & $N$ & $\mathrm{~N}$ & Secondary UHG, THI \\
\hline$D$ & N/D & N/D & & $\mathrm{N}$ & N/D & UHG, THI \\
\hline D & $\mathrm{D}$ & $N / I$ & & $D$ & $\mathrm{~N}$ & HIGM \\
\hline$D$ & $D$ & N/D & & D (P, PS) & N/D & CVID, THI? \\
\hline None & None & None & & & None & Agamm., severe CVID \\
\hline
\end{tabular}

N: Normal; D: Decreased; I: Increased; P: Protein; PS: Polysaccharide; THI: Transient hypogammaglobulinemia of infants; HIGM: Hyperimmunoglobulin M syndrome; UHG: Unspecified hypogammaglobulinemia; SAD: Specific antibody deficiency; IGGSD: Immunoglobulin G subgroup deficiency; SIGAD: Selective IgA deficiency; >ID: Deficiency of one or more than one; Agamm.: Agammaglobulinemia; CVID: Common variable immunodeficiency. 
Table 4. Evaluation of suspected cellular combined immunodeficiency

Tests of primary priority

HIV test (through measuring HIV viral load with anti-HIV and PCR tests)

Immunophenotyping of lymphocytic groups (discrimination between $\mathrm{B}, \mathrm{T}$, and $\mathrm{NK}$ cells )

Skin tests of delayed type hypersensitivity (PPD, Candidin, etc.)

Tests of secondary priority

In vitro T-cell proliferation (mitogen like PHA, alloantigens, etc.)

Flow cytometric evaluation of intracellular proteins or surface antigens in activated T cells, including CD40 ligand (CDI54), IL-2 receptor $\gamma$ chain (CDI32), MHC I and II, IL-7 receptor $\alpha$ chain (CDI27), CD3 zinciri, and WASP Levels of adenozin deaminase (ADA) and purine nucleoside phosphorylase (PNP) enzymes

22 I I FISH test to detect 22q I deletion

TREC levels and T-cell receptor (TCR) analysis

Mutation analyses of known immune deficiency types

Advanced genetic analysis methods

Microarray method (variations in the number of gene copies)

Target gene (target panel) sequencing

All of exome/genome sequences

WASP: Wiskott-Aldrich syndrome protein; FISH: Fluorescent in situ hybridization; TREC: T-cell receptor excision circle.

\section{Lymphocyte count}

Considering lymphocyte counts, it is decided whether or not this patient is $A K I$ after showing that the results are not HIV related. If the $\mathrm{CD}^{+}-\mathrm{T}$ lymphocyte count is $>300$ / $\mathrm{mm}^{3}$, it should be considered that it may be due to the Omenn syndrome maternal engrafmant (the cells passing to the child through the mother) or atypical (leaky) AKI. [8,21] If a low $\mathrm{CD3}^{+}-\mathrm{T}$ lymphocyte count $\left(<300 / \mathrm{mm}^{3}\right)$ is associated with severe neutropenia $\left(<200 / \mathrm{mm}^{3}\right)$, impaired lymphatic proliferation with phenytohemagglutinin (PHA), arrest in myeloid series in the bone marrow, and deafness, the diagnosis of reticular dysgenesis due to the adenylate kinase 2 mutation is considered. ${ }^{[22]}$

\section{Evaluation of lymphocyte function (proliferation)}

It is possible to evaluate the lymphocyte function using different stimuli (mitogen, antigen, and recall antigen). PHA, concanavalin A (ConA), anti-CD3, or pokeweed mitogen are used as mitogens. As an antigen, tetanus and candida are used; as recall antigens, tetanus, monilial, and mumps, which are pathogens that can be easily encountered in each individual's life, are used. Fluorescent dyes such as radioactive nucleoside $3 \mathrm{H}$-thymidine, carboxy fluorescein succinimidyl ester, and cell violet are used to measure immune cell proliferation. ${ }^{[2]}$

T-cell (TCR-V $\beta$ chain) repertoire is normally stable and polyclonal in T lymphocytes. In the presence of clonality or oligoclonality, conditions such as malignancy, infections (HIV, EBV, CMV, etc.), aging, autoimmunity, Omenn syndrome, CID, and atypical DiGeorge syndrome (DGS) should be considered. ${ }^{[6]}$ T-cell receptor (TCR-V $\beta$ chain) repertoire can be investigated using flow cytometry and PCR (spectratyping). ${ }^{[23]}$

\section{T-cell receptor excision circles (TREC) screening test}

These are the residual extracellular DNA residues during the development of $\mathrm{T}$ cells and the formation of the receptor. As $\mathrm{T}$ cells proliferate, these DNA residues become diluted, and their concentration in the cytoplasm may be less difficult to detect. These cells are labeled with $\mathrm{CD}^{+}-\mathrm{CD}^{+} 5 \mathrm{RA}^{+}-\mathrm{CD} 3 \mathrm{I}^{+} \mathrm{T}$ cells with monoclonal antibodies in flow cytometry. This test was originally developed for neonatal screening and early detection of SCIDs. ${ }^{[6,8]}$ Although it cannot detect a type of SCID such as ADA deficiency, it can identify T-cell defects leading to severe lymphopenia with some other CIDs (ataxia-telangiectasia, CHARGE syndrome, DGS, trisomy 21 , leaky [variant] SCID types, etc.). ${ }^{[24,25]}$ Again, it should be known that sometimes in premature cases, false positive results should be obtained. It is also used in the evaluation of immunoreconstitution after hematopoietic stem cell transplantation because it also indicates the presence of naive T cells. ${ }^{[26]}$

\section{3) Evaluation of phagocytic system deficiencies}

If the patient presents with complaints such as delayed detachment of the umbilical cord ( $>$ I months), inflammation without pus, gingivitis and impaired wound healing, we should consider and search for the phagocytic system disorders and examine them. ${ }^{[2-9]}$ We can recognize systemic diseases by measuring the phagocyte cell surface expressions and intracellular oxidative burst.

Measuring surface expressions of phagocytic cells in flow cytometry. A leukocyte adhesion defect (LAD) can be identified by this method. In the flow cytometric examination of peripheral blood, Type I LAD disease is diagnosed by detecting the absence of these expressions in the patient cells by comparing the staining with CDI8/CDI lab-c monoclonal markers used after the neutrophil-phagocyte cell uptake. ${ }^{[4,8]}$ Type 2 LAD is diagnosed if the CDI5 expression is not found in patient cells. ${ }^{[8]}$

\section{Nitroblue tetrazolium reduction test}

Nitroblue tetrazolium (NBT) solution is a colorless or pale yellow (when oxidized) chemical substance. Formazan is formed when oxidized by oxidase in the neutrophils (phagocytes) (with the production of superoxides by oxidative burst), and the cell cytoplasm becomes dark blue. Microscopic examination normally shows neutrophils with blue-stained cytoplasm. It is possible to make assessments using (evoked) or not using stimuli (nonevoked). The method is semiquantitative and subjective. X-chronic granulomatous disease may overlook carrier and hypomorphic mutations. Stimulated (evoked) control cells 
Table 5. Complement system evaluation

\begin{tabular}{ccll}
\hline CH50 & AH(AP)50 & Possible diagnosis & Concomitant disease \\
\hline $\mathrm{N}$ & $\mathrm{N}$ & Normal (MBL deficiency?) & Normal (infection with encapsulated bacteria) \\
$\mathrm{N}$ & $\downarrow$ & Properdin defect (PSGN?) & Neisseria infection, lupus-like disease \\
$\mathrm{N}$ & 0 & Factor B/D defect & Atypical HUS/Infection (encapsulated bacteria) \\
$\downarrow$ & $\mathrm{N} / \downarrow$ & Regulatory Factor H/I defect, consumption & Atypical HUS/Infection (encapsulated bacteria) \\
0 & $\mathrm{~N}$ & Cl-C9 deficiency (classical /terminal route) & Neisseria and Infection (encapsulated bacteria) \\
& & C9 deficiency: I/4-I/2 of normal & \\
0 & $\mathrm{~N}$ & SLE & Systemic lupus erythematosus \\
& 0 & C3; C5-C9 deficiency & Neisseria and infection (encapsulated bacteria)
\end{tabular}

N: Normal; $\downarrow$ : Decreased; MBL: Mannose-binding lectin; PSGN: Poststreptococcal glomerulonephritis; HUS: Hemolytic uremic syndrome; CH50: Total hemolytic complement activity; $A H(A P) 50$ : Alternative pathway hemolytic activity.

demonstrate a $\geq 90 \%$ positivity (blue staining in cells), and a $\leq 10-90 \%$ positivity is observed in the phagocytic cells of the disease carriers. If there is a $\leq 70 \%$ positivity in evoked phagocytic cells, disease or carriership should be considered. As oxidative explosion disorders, chronic granulomatous disease (CGD), complete glucose-6-phosphate dehydrogenase, and myeloperoxidase (MPO) deficiency should be considered. ${ }^{[27,28]}$ It appears that, nowadays, this test is replaced by a below-mentioned dihydro-rhodamine (DHR) test.

Dihydro-rhodamine 1,2,3 or 2'7, dichlorofluorosein diacetate tests

These can be performed in flow cytometry, which is developed to measure oxidation (oxidative burst) in the cell, and they are now becoming more popular and accepted as the alternative tests to gold standard NBT test. In their evaluation, the mean fluorescence index on the histogram after the oxidation increases, and the right shift is observed. ${ }^{[29]}$ This test used instead of NBT seems to be superior to NBT in detecting carriers and other types of CGD (autosomal or X-linked). ${ }^{[30]}$

\section{Determination of myeloperoxidase deficiency}

This disease, which is usually asymptomatic, autosomal recessive, and has a frequency of $1: 4,000$ is also known as the most common phagocyte system defect. In the myeloperoxidase deficiency contained in the azurophilic granules, some cells are found to be unstained with routine dyes (benzidine-containing hydrogen peroxide/ethanol solution), and the difference between the counts on the hemogram. ${ }^{[3]}$ Reactive increases the toxicity of oxygen radicals. There is an increase in Candida and Aspergillus infections and diabetes mellitus. In addition, MPO deficiency in the flow cytometry to gate phagocytic cells (gate) is done by monoclonal marking in the cell containing myeloperoxidase. ${ }^{[32,33]}$

\section{4) Evaluation of immune dysregulation disorders}

Immunodeficiency diseases should be considered if there are findings suggestive of specific lymphadenopathy, hepatosplenomegaly, or autoimmune diseases. In addition to other laboratory and clinical findings, flow cytometric investigations are used in the foreground and most frequently. For example, autoimmune lymphoproliferative syndrome (ALPS) from immune dysregulation diseases is one of the first that comes to our mind. Elevated levels of serum BI2 (>1500 ng/l), plasma FasL (>200 pg/ml), IL- I0 $(20 \mathrm{pg} / \mathrm{ml})$, and IL-I8 $(500 \mathrm{pg} / \mathrm{ml})$ are also helpful in the diagnosis of ALPS. ${ }^{[27,34,35]}$

Detection of the most common immune dysregulation disorders in flow cytometry

In the flow cytometry, the diagnosis of apoptosis in double negative $\mathrm{T}$ cells $\left(\mathrm{CD}^{+}{ }^{+}-\mathrm{CD} 4-\mathrm{CD} 8-\mathrm{TCR}^{\alpha \beta^{+}}\right)(>2.5 \%)$ is helpful in the diagnosis. ${ }^{[34,35]}$ Decreased LAMP (CDI07a) expression is seen in flow cytometry in diseases with immunodeficiency disorders (familial hemophagocytic lymphohistiocytosis). ${ }^{[36]}$ In addition, X-linked lymphoproliferative syndromes Type I and Type 2 (XLPI and XLP2) can also be identified by flow cytometric examination based on the expression of SAP and XIAP. ${ }^{[38]}$

\section{5) Complement deficits assessment}

The prevalence of complement deficiencies (complementopathy) is known to be $0.03 \%$ in the community. ${ }^{[39]}$ We should consider the lack of complement in the clinic when we encounter disease tables such as Neisseria meningitis, SLE, (typical or atypical) hemolytic uremic syndrome, and paroxysmal nocturnal hemoglobinuria (Table 5).

\section{How should we evaluate the complement system?}

$\mathrm{CH} 50$ and $\mathrm{AH}$ (AP) 50 tests are used to evaluate classical and alternative complement pathways. The $\mathrm{CH} 50$ test is as low as zero, and when AH (AP) 50 is normal, it suggests a lack of one of the classic complement pathway elements $\mathrm{Cl}-\mathrm{C} 9$. Only in $\mathrm{C} 9$ deficiency, the $\mathrm{CH} 50$ will be reduced by no more than $50 \%$. If the $\mathrm{CH} 50$ level is higher than zero, consumption-related deficiency should be considered in diseases such as SLE. When AH (AP) 50 is zero and $\mathrm{CH} 50$ is normal, the Factor $B / D$ deficiency of the alternative pathway should be considered. The values of $\mathrm{AH}$ (AP) 50, which are higher than zero, are seen in Factor $\mathrm{H} / \mathrm{l}$ and properdin deficiency (Table 5). 
Table 6. Simple screening or advanced stage tests according to primary immune deficiency disease group

\begin{tabular}{|c|c|}
\hline Simple tests & Advanced stage tests \\
\hline \multicolumn{2}{|l|}{ Evaluation of humoral immunity } \\
\hline Serum immunoglobulin isotype level & Cell subgroup counts (as naive and class-switched memory cells) \\
\hline $\begin{array}{l}\text { Serum-specific antibody level (natural or before booster } \\
\text { dose of the vaccine) }\end{array}$ & $\begin{array}{l}\text { In vitro immunoglobulin production as a response to } \\
\text { mitogen or other stimuli }\end{array}$ \\
\hline Antibody response to booster the dose of vaccine & $\begin{array}{l}\text { Antibody response after immunization with } \phi \times 174 \\
\text { bacteriophage }\end{array}$ \\
\hline \multicolumn{2}{|l|}{ Absolute B-cells counts in flow cytometry } \\
\hline \multicolumn{2}{|l|}{ Evaluation of cellular immunization } \\
\hline TREC screening in newborn & $\begin{array}{l}\text { Flow cytometry for the evaluation of T-cell subgroup } \\
\text { counts (naive, memory, and active cells) }\end{array}$ \\
\hline Flow cytometry for the measurement of CD4+ and CD8+ & In vitro proliferative response against mitogens and antigens \\
\hline \multicolumn{2}{|l|}{ T cells and NK cells } \\
\hline Delayed cutaneous type hypersensitivity & T-cell cytotoxicity \\
\hline NK (natural killer) cell cytotoxicity & $\begin{array}{l}\text { Evoked in vitro cytokine production and expression of } \\
\text { surface markers }\end{array}$ \\
\hline \multicolumn{2}{|l|}{ Evaluation of phagocytic system cells } \\
\hline Profile of blood cells (differential count) & Evaluation of chemotaxis and/or pathway of phagocytosis \\
\hline Staining and morphology of neutrophils in peripheral smear & Measurement of enzyme levels (myeloperoxidase, G6PDH) \\
\hline $\begin{array}{l}\text { Dihydro-rhodamine (DHR) and nitroblue tetrazolium } \\
\text { (NBT) test }\end{array}$ & Measurement of leucocyte degradation rate \\
\hline $\begin{array}{l}\text { Flow cytometric evaluation of adhesion molecules } \\
\text { (CDI5, CDI8) }\end{array}$ & Bacterial and fungal killing ability \\
\hline Bone marrow biopsy & \\
\hline \multicolumn{2}{|l|}{ Evaluation of complement system (complementopathy) } \\
\hline Measurement of $\mathrm{CH} 50$ (total hemolytic complement activity) & $\begin{array}{l}\text { Analysis of levels or functions of specific complement } \\
\text { components }\end{array}$ \\
\hline \multicolumn{2}{|l|}{ Measurement of AH50 (alternative hemolytic activity pathway) } \\
\hline Investigation of the lectin pathway function & \\
\hline
\end{tabular}

\section{Determination of complement deficiencies in flow} cytometry

Recently, Özen et al..$^{[40]}$ described the expression deficiency of one of the complement regulator proteins (CD55). Because of the initials of the symptoms in English, CHAPLE is also known as the CD55 deficiency, angiopathic thrombosis and protein-losing enteropathy syndrome with complement hyperactivity. Also, paroxysmal nocturnal hemoglobinuria with hemolysis, thrombosis, and polyneuropathy due to lack of expression of the membrane attack complex inhibitor (CD59) has been described.

\section{6) Natural/structural immune disorders}

These disorders of the immune system are susceptible to tuberculosis and some viral (human herpes and papilloma) infections. The susceptibility to tuberculosis infections occurs with the lack of expression of certain cytokines and receptors (IFN- $\gamma \mathrm{RI}$, IL-I2, and IL-23R $\beta \mathrm{I}$ ). ${ }^{[43]}$ Some viral (human herpes and papilloma virus) susceptibility to infections may occur due to CDI6, TLR3 pathway deficiencies. ${ }^{[8,44,45]}$ Again, susceptibility to invasive bacterial infections as an indicator of IRAQ4 deficiency may be seen with granulocytes and CD62L shedding disorder. The susceptibility to chronic mucocutaneous candidiasis goes with a lack of the IL-I7F/RA/RC expression. ${ }^{[10,46]}$ Flow cytometry is able to measure these cytokines and their receptors, as well as the surface protein expression such as CDI6, TLR3, and CD62L.

In summary, the most commonly seen and considered four (humoral, cellular/combined, phagostic, and complement disorders) disorders from this review are summarized in Table 6 as a large PID group.

\section{CONCLUSION}

Primary immunodeficiencies are very heterogeneous and more common than we think. The recognition SCID cases is a pediatric emergency. The knowledge of simple diagnostic/screening tests by each physician will allow an easy and quick evaluation. Genetic and advanced tests, which can only be performed in certain centers, have an important role in the diagnosis of a large part of PIDD. 
Early guidance and interpretation of these tests will increase the chance of early diagnosis and treatment in the centers that will perform these simple and advancedstage tests.

\section{Conflict of Interest}

\section{None declared.}

\section{REFERENCES}

1. 10 Warning Signs - JMF - Jeffrey Modell FoundationMedicaladvisory Board. Available at: http://www.info4pi.org/library/educationalmaterials/10-warning-signs. Accessed February 20, 2019.

2. Shearer WT, Buckley RH, Engler RJM, Finn AF, Fleisher TA, Freeman T, et al. Practice parameters for the diagnosis and management of immunodeficiency. The clinical and laboratory immunology committee of the American Academy of Allergy, Ashtma, and Immunology (CLIC-AAAAI). Ann Allergy Asthma Immunol 1996;76:282-94.

3. Bonilla FA, Bernstein IL, Khan DA, Ballas ZK, Chinen J, Frank MM, et al; American Academy of Allergy; American College of Allergy, Ashtma and Immunology; Joint Council of Allergy, Ashtma and Immunology.. Practice parameter for the diagnosis and management of primary immunodeficiency. Ann Allergy Asthma Immunol 2005;94:S1-63. [CrossRef]

4. Notarangelo LD, Fischer A, Geha RS, Casanova J-L, Chapel H, Conley ME, et al; International Union of Immunological Societies Expert Committee on Primary Immunodeficiencies. Primary immunodeficiencies: 2009 update. J Allergy Clin Immunol 2009;124:1161-78.

5. Notarangelo LD. Primary immunodeficiencies. J Allergy Clin Immunol 2010;125:S182-94. [CrossRef]

6. Oliveira JB, Fleisher TA. Laboratory evaluation of primary immunodeficiencies. J Allergy Clin Immunol 2010;125:S297-305. [CrossRef]

7. Parvaneh N, Casanova JL, Notarangelo LD, Conley ME. Primary immunodeficiencies: a rapidly evolving story. J Allergy Clin Immunol 2013;131:314-23. [CrossRef]

8. Bonilla FA, Khan DA, Ballas ZK, Chinen J, Frank MM, Hsu JT, et al. Practice parameter for the diagnosis and management of primary immunodeficiency. J Allergy Clin Immunol 2015;136:1186-205. e1-78.

9. Routes J, Abinun M, Al-Herz W, Bustamante J, Condino-Neto A, De La Morena MT, et al. ICON: the early diagnosis of congenital immunodeficiencies.. J Clin Immunol 2014;34:398-424. [CrossRef]

10. Bousfiha A, Jeddane L, Picard C, Ailal F, Bobby Gaspar H, Al-Herz W, et al. The 2017 IUIS phenotypic classification for primary immunodeficiencies. J Clin Immunol 2018;38:129-43. [CrossRef]

11. Kilic SS, Ozel M, Hafizoglu D, Karaca NE, Aksu G, Kutukculer N. The prevalences [correction] and patient characteristics of primary immunodeficiency diseases in Turkey-two centers study. J Clin Immunol 2013;33:74-83. [CrossRef]

12. Kılıç M, Taşkın E, Selmanoğlu A. Primer immün yetmezlikli olgularımızın retrospektif değerlendirilmesi. Fırat Tip Derg 2015;20:3742.

13. Aldırmaz S, Yücel E, Kıykım A, Çokuğraş H, Akçakaya N, Camcıŏlu Y. Profile of the patients who present to immunology outpatient clinics because of frequent infections. Turk Ped Archiv 2014;49:210-6.

14. Uygun DFK, Hafızoğlu D. Primer immun yetmezlik hastalarımızın retrospektif değerlendirilmesi; Erzurum deneyimi. Asthma Allergy Immunol 2015; 13:90-3.

15. Misirlioğlu ED, Tayfur G, Doğru M, Duman H, Özmen S, Aytekin C. Allerji kliniğinde izlenen hastalarda primer antikor eksiklikleri. Türkiye Çocuk Hast Derg 2010;4:219-23.

16. Aksu G, Genel F, Koturoğlu G, Kurugöl Z, Kütükçüler N. Serum immunoglobulin ( $\operatorname{Ig} G, \operatorname{IgM}, \operatorname{Ig} \mathrm{A})$ and $\operatorname{IgG}$ subclass concentrations in healthy children: a study using nephelometric technique. Turk J Pediatr 2006;48:19-24.

17. Baskın Y, Yiğitbaşı T, Afacan G, Akgün F, Dere R. Sağlıklı Bireylerde İmmunoglobulin (IGA, IGG, IGM) ve IGG alt grupları referans aralıkları. Turk J Biochem 2010;35;325-32.

18. Lee PP, Chen TX, Jiang LP, Chan KW, Yang W, Lee BW, et al. Clinical characteristics and genotype-phenotype correlation in 62 patients with X-linked agammaglobulinemia. J Clin Immunol 2010;30:12131. [CrossRef]

19. Winkelstein JA, Marino MC, Lederman HM, Jones SM, Sullivan K, Burks AW, et al. X-linked agammaglobulinemia: report on a United States registry of 201 patients. Medicine (Baltimore) 2006;85:193202. [CrossRef]

20. Fong SW, Qaqundah BY, Taylor WF. Developmental patterns of $\mathrm{ABO}$ isoagglutinins in normal children correlated with the effects of age, sex, and maternal isoagglutinins. Transfusion 1974;14:551-9.

21. Shearer WT, Dunn E, Notarangelo LD, Dvorak CC, Puck JM, Logan BR, et al. Establishing diagnostic criteria for severe combined immunodeficiency disease (SCID), leaky SCID, and Omenn syndrome: the Primary Immune Deficiency Treatment Consortium experience.J Allergy Clin Immunol 2014;133:1092-8. [CrossRef]

22. Pannicke U, Honig M, Hess I, Friesen C, Holzmann K, Rump EM, et al. Reticular dysgenesis (aleukocytosis) is caused by mutations in the gene encoding mitochondrial adenylate kinase 2. Nat Genet 2009;41:101-5. [CrossRef]

23. Pilch H, Hohn H, Freitag K, Neukirch C, Necker A, Haddad P, et al. Improved assessment of T-cell receptor (TCR) VB repertoire in clinical specimens: combination of TCR-CDR3 spectra typing with flow cytometry-based TCR VB frequency analysis. Clin Diagn Lab Immunol 2002;9:257-66. [CrossRef]

24. laMarca G, Canessa C, Giocaliere E, Romano F, Duse M, Malvagia S, et al. Tandem mass spectrometry, but not T-cell receptor excision circle analysis, identifies newborns with late-onset adenosine deaminase deficiency. J Allergy Clin Immunol 2013;131:1604-10. [CrossRef]

25. Brown L, Xu-Bayford J, Allwood Z, Slatter M, Cant A, Davies EG, et al. Neonatal diagnosis of severe combined immunodeficiency leads to significantly improved survival outcome: the case for newborn screening. Blood 2011;117:3243-6. [CrossRef]

26. Özdemir O. Neonatal screening test for severe combined immunodeficiency of primary immunodeficiency diseases: TREC assay and its limitations. MOJ Immunol 2016;3:00107. [CrossRef]

27. Nima Rezaei, Asghar Aghamohammadi, Luigi D. Notarangelo, editors. Primary Immunodeficiency Diseases. Berlin: Springer; 2008.

28. Chinen J, Paul ME, Shearer WT. Approach to the Evaluation of the immunodeficient patient. In: Rich RR, Fleisher TA, Shearer WT, Schroeder HW Jr, Frew A, Weyand C, editors. Clinical immunology: principles and practice. London: Elsevier; 2012. pp. 1-31.

29. Özdemir Ö, Karavaizoğlu Ç. Akım sitometrinin immünolojik ve alerjik hastalıklarda kullanımı. Asthma Allergy Immunol 2016;14:117-28.

30. Köker MY, Camcioğlu Y, van Leeuwen K, Kılıç SŞ, Barlan I, Yılmaz $\mathrm{M}$, et al. Clinical, functional, and genetic characterization of chronic granulomatous disease in 89 Turkish patients. J Allergy Clin Immunol 2013;132:1156-63.e5. [CrossRef]

31. Parry MF, Root RK, Metcalf JA, Delaney KK, Kaplow LS, Richar WJ. Myeloperoxidase deficiency: prevalence and clinical significance. Ann Intern Med 1981;95:293-301. [CrossRef]

32. Nauseef WM. Diagnostic assays for myeloperoxidase and myeloperoxidase deficiency. Methods Mol Biol 2014;1124:537-46. [CrossRef]

33. Savaşan S, Buck S, Gadgeel M, Gabali A. Flow cytometric false myeloperoxidase-positive childhood B-lineage acute lymphoblastic leukemia. Cytometry B Clin Cytom 2018;94:477-83. [CrossRef] 
34. Madkaikar M, Mhatre S, Gupta M, Ghosh K. Advances in autoimmune lymphoproliferative syndromes. Eur J Haematol 2011;87:1-9.

35. Teachey DT. New advances in the diagnosis and treatment of autoimmune lymphoproliferative syndrome. Curr Opin Pediatr 2012;24:1-8.

36. Bryceson YT, Pende D, Maul-Pavicic A, Gilmour KC, Ufheil H, Vraetz $\mathrm{T}$, et al. A prospective evaluation of degranulation assays in the rapid diagnosis of familial hemophagocytic syndromes. Blood 2012;119:2754-63. [CrossRef]

37. Marsh RA, Bleesing JJ, Filipovich AH. Using flow cytometry to screen patients for X-linked lymphoproliferative disease due to SAP deficiency and XIAP deficiency. J Immunol Methods 2010;362:1-9.

38. Ozdemir O, Ravindranath Y, Savaşan S. Cell-mediated cytotoxicity evaluation using monoclonal antibody staining for target or effector cells with annexin $\mathrm{V} /$ propidium iodide colabeling by fluorosphere-adjusted counts on three-color flow cytometry. Cytometry A 2003;56:53-60. [CrossRef]

39. Wen L, Atkinson JP, Giclas PC. Clinical and laboratory evaluation of complement deficiency. J Allergy Clin Immunol 2004;113:585-93.

40. Ozen A, Comrie WA, Ardy RC, Domínguez Conde C, Dalgic B, Beser ÖF, et al. CD55 Deficiency, Early-Onset Protein-Losing Enteropathy, and Thrombosis. N Engl J Med 2017;377:52-61.

41. AlGhasham N, Abulkhair Y, Khalil S. Flow cytometry screening for paroxysmal nocturnal hemoglobinuria: A single-center experience in Saudi Arabia. Cytometry B Clin Cytom 2015;88:389-94. [CrossRef]

42. Nevo Y, Ben-Zeev B, Tabib A, Straussberg R, Anikster Y, Shorer $Z$, et al. CD59 deficiency is associated with chronic hemolysis and childhood relapsing immune mediated polyneuropathy. Blood 2013;121:129-35. [CrossRef]

43. Hoshina T, Takada H, Sasaki-Mihara Y, Kusuhara K, Ohshima K, Okada S, et al. Clinical and host genetic characteristics of Mendelian susceptibility to mycobacterial diseases in Japan. J Clin Immunol 2011;31:309-14. [CrossRef]

44. Grier JT, Forbes LR, Monaco-Shawver L, Oshinsky J, Atkinson TP, Moody C, et al. Human immunodeficiency-causing mutation defines CD16 in spontaneous NK cell cytotoxicity. J Clin Invest 2012;122:3769-80. [CrossRef]

45. Guo Y, Audry M, Ciancanelli M, Alsina L, Azevedo J, Herman M, et al. Herpes simplex virus encephalitis in a patient with complete TLR3 deficiency: TLR3 is otherwise redundant in protective immunity. J Exp Med 2011;208:2083-98. [CrossRef]

46. Puel A, Doffinger R, Natividad A, Chrabieh M, Barcenas-Morales G, Picard C, et al. Autoantibodies against IL-17A, IL-17F, and IL-22 in patients with chronic mucocutaneous candidiasis and autoimmune polyendocrine syndrome type I.J Exp Med 2010;207:291-7. [CrossRef]

\section{Primer İmmün Yetersizlik Hastalıklarına Güncel Yaklaşım}

Primer immnün yetersizlik hastalıkları (PiYH) insan bağışılık sisteminin değişik bileşenlerindeki bozukluklar sonucu oluşan kalıtsal bozukluklardır. Günümüzde 330'dan daha fazla PiYH tanımlanmıştır ve bunların 320'den fazlasının moleküler (genetik) temelleri bilinmektedir. Primer immün yetersizlikler 9 farklı grupta (antikor-humoral-yetersizlik, kombine ( $T$ ve B hücre) immün yetersizlik, doğal/intrensek yetersizlikler, fagositik, kompleman sistem bozuklukları, sendromik immün yetersizlikler, immün disregülasyon hastalıkları, otoenflamatuvar bozukluklar, PiY fenokopileri) incelenebilirler. PiYH grubu içinde primer antikor eksiklikleri en sık rastlanan gruptur ve PiYH'nin yaklaşık yarısından fazlasından sorumludur. Doğuştan primer immün yetersizlikler geç başlangıçlı olarak artan oranda tanınmasına rağmen, tipik olarak yaşamın erken döneminde belirti verirler. Hastalığa yakalananlar klinik olarak genellikle tekrarlayan, ciddi enfeksiyonlar veya değişik otoimmün veya diğer hastalıkları taklit eden klinik tablolarla karşımıza çıkar. Doğuştan immün yetersizliklerin erken teşhisi hastanın özel tedavi merkezlerine yönlendirilmesi, transplantasyonu dâhil en uygun tedavinin bir an önce başlaması ve ve daha uzun yaşam şansı için önem arz etmektedir. Bu yazıda, immün yetersizliği düşündüren tipik klinik bulgular ve/veya enfeksiyonlarla karşılaşan klinisyen için en sık görülen PiYH'lerin araştırılmasında istenecek en uygun laboratuvar incelemeleri genel bir yaklaşım içinde anlatılmaktadır.

Anahtar Sözcükler: Ağır kombine immün yetersizlik; kombine immün yetersizlik; primer immün yetersizlik hastalığ; teşhis. 